\title{
Synthesis of Research on Mathematical Thinking Development under the Lesson Study and Open Approach Context
}

\section{| Jatuporn Nasinsroy ${ }^{1,2}$ | Maitree Inprasitha ${ }^{1,2^{*}} \mid$ Narumon Changsri ${ }^{1,2}$ |}

${ }^{1}$ Mathematics Education

Program, Center for Research

in Mathematics Education,

Khon Kaen University, Khon

Kaen, Thailand

${ }^{2}$ Center for Research in

Mathematics Education, Khon

Kaen University, Khon Kaen,

Thailand

1jatuporn_n@kkumail.com

2inprasitha_crme@kku.ac.th

\begin{abstract}
The qualitative educational research synthesis of this paper is the incorporation of existing knowledge and the research results using Lesson Study and Open Approach innovations that relevant to the concern of students' mathematical thinking development. The purpose of synthesis is to upsurge the generalization and pertinency of new knowledge development based on the results in incorporation the two innovations. Researchers employed document analysis to analyze the evidence of 266 postgraduate studies from the academic year 2003 to 2020. The research procedure consists of three stages. The results from the first stage showed that there are six research classifications identified, namely teacher and teaching, students and learning, assessment, classroom innovations, curriculum development, and educational policy. The research findings of the second phase indicated that there was a total of 210 studies (78.95\%) were employing Open Approach incorporated in the Lesson Study process. Moreover, 53.33 percent are found in students and learning research classification. This is followed by 19.05 percent in teacher and teaching, 14.76 percent in classroom innovations, and 4.76 percent in assessment classifications. However, there was a limited of past postgraduate researchers interested to study curriculum development (4.29\%) and educational policy (3.81\%) research classifications. The findings of the final stage revealed that all the 210 postgraduate studies concerning the six research classifications are found to have different impacts on students' mathematical thinking development. These effects occurred across a series of settings, synthesis approaches, expectations, and managing the Thailand Lesson Study Model.

KEYWORDS;

innovations; lesson study; mathematical thinking; open approach; synthesis of educational research.
\end{abstract}

\section{INTRODUCTION}

Research synthesis is defined by past researchers (Baron et al., 2017; Wyborn et al., 2018) as the incorporation and valuation of understanding and study results relevant to a specific problem, with the intention of enhancing the generalization and application of, and gain access to, those results. Qualitative educational research synthesis is an academic report to facilitate the research of teachers and students' teaching and learning experiences as well as cultural and social phenomena (Jordan, Donnelly, \& Pittman, 2006). Therefore, qualitative educational research synthesis has its foundations in the humanities and social sciences and requests to examine the complication of human being experiences in realistic backgrounds and from a universal perspective (Ailinger, 2003). 
The significance of systematic reviews of postgraduate research in utilizing teaching innovations could inform us of the delivery of the teaching and learning process as evidencebased teacher education (Lockwood, Munn, \& Porritt, 2015). As a result, systematic reviews can investigate the culture of school communities, exploring students' experiences and teachers' teaching practices through the Lesson Study (LS) process, and can evaluate the implementation of Open Approach (OA) and mathematical activities of research lessons as teacher professional development (Munn, Porritt, Lockman, \& Aromataris, 2014).

National Council of Teachers of Mathematics (NCTM) (2000) proposed the sociocultural models such as the LS model of teaching and learning to be the powerful references in teachers' ability to describe and support the search of instruction. Students are expected to participate actively in their own learning and can select from a repertoire of approaches and their progress in utilizing these approaches toward their learning goal (Pape, Bell, \& Yetkin, 2003). Even though there is an abundance of literature emphasizing the importance to focus on enhancing students' mathematical thinking while they are learning mathematics, but the effect of research synthesis on educational policy and practice and the rationality of the expectations supporting effect have hardly ever been studied analytically (Abdul Hamid \& Kamarudin, 2021). The creation of new ideas is recognized as a substantial component in learning mathematics (Lee \& Bailey, 2020) because it is directly related to the cognitive capabilities or creative thinking of a student to solve mathematical problems (Ghazali, Nordin, Abdullah, \& Ayub, 2020).

LS is recognized as one of the highly implemented models of teacher professional development, as stated by Hrastinski (2021). This is because a team of teachers cooperatively plans a lesson in detail and then observes and analyzes the lesson (Lewis, Perry, Murata, 2006). Moreover, the LS model has been proved by past researchers (Vermunt, Vrikki, van Halem, Warwick, \& Mercer, 2019) to have a valuable influence on the excellence of teacher learning as well as pedagogical content knowledge (Coenders \& Verhoef, 2019). Barber (2018) stressed the advantage of using LS as an effective method for mathematics teachers to shift their instruction because LS sets the stage for continuous improvement of teaching (Murata, 2011). This is in line with the definition given by Stigler and Hiebert (1999). They defined LS as a long-term, gradual transformation process, concentrates on student learning, research, and collaboration, and compliments the cultural nature of teaching.

OA is comprised of two phases, namely the Problem Posing phase and the Problemsolving phase encompassing four steps. This original idea of OA was proposed by Inprasitha $(2004 ; 2011$; 2015a) including the following characteristics. For example, OA is a teaching innovation to enhance students' learning experiences by allowing students to have greater autonomy to work with mathematical concepts (English, 2020), sharing their mathematical ideas with their peers, and challenging problem situations that aligned with the student's abilities (Leikin \& Elgrably, 2020). Moreover, OA makes the teaching and learning process student-centered as it is designed to provide maximum gain to students thus reach their learning outcomes (Lalima \& Dangwal, 2017). On the other hand, teachers who are applying $\mathrm{OA}$ in their teaching, act as a motivator, resource person, and organizer to create relevant problem situations for developing their students' mathematical thinking (Lalima \& Dangwal, 2017).

The two innovations, namely LS and OA were adapted by Inprasitha (2004; 2009) respectively for changing and improving the paradigm of teaching practices in the Thai context. Hence, Inprasitha (2011) managed to create the Thailand LS Model as elucidated in Figure 1. The LS process consists of three steps: (i) Collaboratively design research lesson (Plan); (ii) Collaboratively observe research lesson (Do), and (iii) Collaboratively reflect on teaching practice (See) while the OA is comprised of four steps: (i) Posing open-ended 
problem; (ii) Students' self-learning; (iii) Whole class discussion and comparison, and (iv) Summarize through connecting students' mathematical ideas emerged in the classroom (Inprasitha, 2015b).

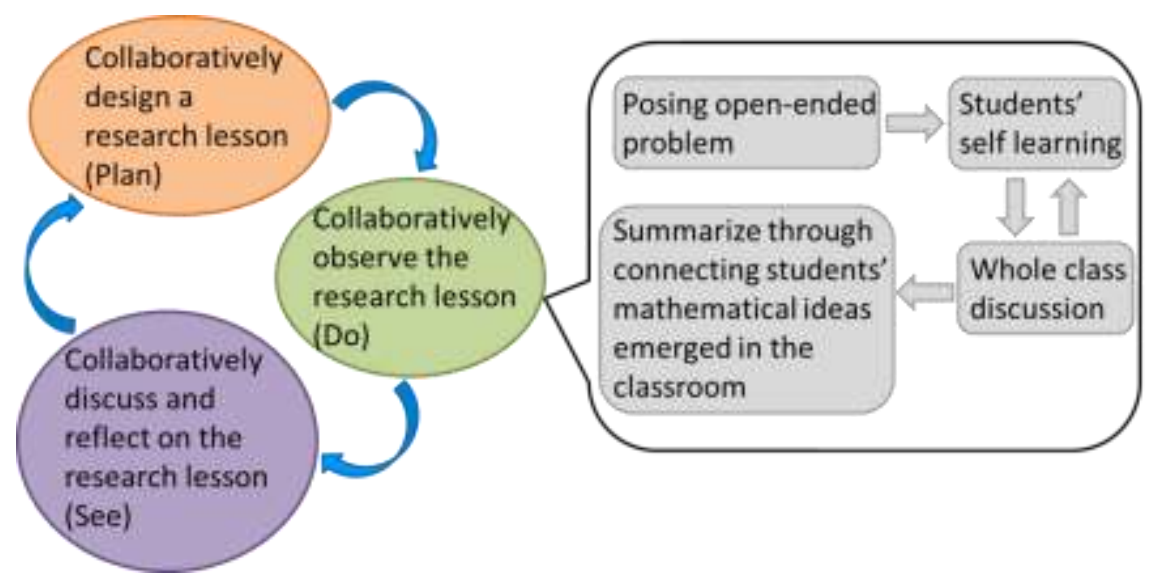

Figure 1. Thailand LS Model

The Thailand LS Model is a procedure of generating sharable, adaptable, and eco-friendly devices for communicating, expecting, and operating realistic circumstances, as defined by Lesh and Doerr (2003) who considered this process as mathematical modeling. According to Kertil and Gurel (2016), mathematical modeling applications support students with important community theoretical advancements and significant understanding of fundamental mathematical real situations. In this line of reasoning, a review of past postgraduate studies was aimed to provide on how mathematical literature would promote to the hypothetical conceptualization of mathematical thinking by precisely delivering the methods of mathematical thinking that could be developed. Many researchers in Thailand have indicated the need for the Thailand LS Model applications to develop students' mathematical reasoning capability, problem-solving abilities, and analytical thinking abilities while they are learning mathematics in school (Chaona, Inprasitha, Changsri, \& Sangaroon, 2021; Jitlada, Inprasitha, \& Changsri, 2021; Kesorn, Junpeng, Marwiang, Pongboriboon, Tang, \& Wilson, 2020; Laah-on, Inprasitha, Sangaroon, \& Changsri, 2021; Manmai, Inprasitha, Changsri, \& Pattanajak, 2020).

In this study, mathematical thinking refers to higher-order thinking focusing on students think by/for themselves. (Shimizu, 1999; Inprasitha, 2004; 2015a). Therefore, Stacey (2006) defined mathematical thinking as the capability to think mathematically and to apply mathematical thinking to solve problems in order to achieve the important goal of learning mathematics. According to Schoenfeld's (1985) mathematical problem-solving framework, it indicates that there are four mathematical thinking components, namely the resources of mathematical knowledge in resolving problems, the observing, and control that the students apply on the problem-solving procedure to lead it in creative instructions, and the principles that the students hold about mathematics, either permit or restrict their problem-solving efforts. This is further supported by Isoda and Katagiri (2012) who emphasized the importance to express students' ideas in solving mathematical problems.

\section{RESEARCH METHODS}

The research method used in this study was to synthesize the evidence of a total of 266 studies from the academic year 2003 to 2020 . A systematic review was employed to classify the research findings of the postgraduate mathematics education research in using the 
theoretical perspective of incorporating OA at the second step of the LS process for mathematical thinking development. There were 179 master's studies in the academic year 2013 to 2017 from Science and Technology program majoring in teaching high school mathematics, 52 doctoral degree research and 35 master's degree research in Mathematics Education program from the academic year 2006 to 2020, made up a total of 266 research documents for investigation.

Document analysis as a type of qualitative research method where all the 266 postgraduate theses were translated by the researchers to give voice and meaning around the assessment topic as mathematical thinking development was the key content to investigate (Bowen, 2009). Researchers analyzed the documents by incorporating coding content into themes (Bowen, 2009). A rubric was used as a research instrument to grade or score the 266 documents (O’Leary, 2014).

The rationale of using document analysis is because it is a social research method for an important element of greatest ideas of triangulation as well as the blend of approaches in the research of the similar occurrence (Bowen, 2009). Besides, researchers would like to pursue convergence and justification through using distinct data resources and practices. Justification findings across data sets could assist researchers to decrease the effect of probable favoritism by inspecting data composed through various sources. The research procedure was not just a process of covering up a assortment of quotations that conveying anything the researchers desired to find out but also a extreme level of independence and understanding must be maintained in order for the document analysis outcomes to be reliable and useable (Bowen, 2009).

Researchers started using content analysis to analyze the 266 postgraduate theses, followed by thematic analysis, which could be measured a method of design acknowledgment with the document's data (Bowen, 2009). As a result, researchers took the evolving themes and made them into groups for additional examination, constructing it a beneficial exercise for grounded theory. Researchers did a cautious, attentive understanding, and re-reading of data before researchers constructed the coding and category. The evolving codes and themes might assist to integrate data accumulated from diverse procedures. Finally, researchers tallied up the inclusive idea of document analysis as a procedure of assessing the 266 postgraduate theses in such a way that experimental data was formed, and understanding was established.

\section{RESULTS AND DISCUSSION}

\section{Results of Postgraduate Studies Classification}

Synthesis initiatives and associated impacts could be analyzed without isolation of their current and historical context, or of the processes used to conduct synthesis, as highlighted by Wyborn et al. (2018). Romberg (1969, cited in Kilpatrick, 1992) claimed that there were more than 1,000 studies on the teaching and learning of mathematics. Romberg referred to mathematics education studies classification as the stimulation in mathematics education with a new curriculum developed in the 1960s and the growing interest and involvement of mathematicians and psychologists in the study of mathematical learning and teaching. The mathematics education research classifications were as follow: (a) association; (b) activity learning; (c) creative behavior; (d) teaching; (e) effectiveness of instructional programs; (f) learner characteristics associated with achievement; (g) attitudes, and (h) evaluation of achievement. The Third International Congress on Mathematical Education in Karlsruhe noticed the change of mathematics education research interests from students and curriculum perspectives to teachers' perspectives, with a greater focus on real classroom situations and the social context of learning (Kilpatrick, 1992; p. 27). In 2003, the above concept was 
applied for a postgraduate program in mathematics education to classify their research group (Inprasitha, 2004). Table 1 shows the six research groups by following Inprasitha's (2004) identified classifications with their related research issues.

Table 1. Postgraduate Studies Classification

\begin{tabular}{|c|c|c|}
\hline $\begin{array}{l}\text { Research } \\
\text { Group }\end{array}$ & $\begin{array}{c}\text { Name of Research } \\
\text { Group }\end{array}$ & Research Issues \\
\hline $\begin{array}{l}\text { Research } \\
\text { Group } 1\end{array}$ & $\begin{array}{c}\text { Teacher and } \\
\text { Teaching }\end{array}$ & $\begin{array}{l}\text { Issues about Pre-service Teacher: Pre-service Mathematics } \\
\text { Teacher Education Models, Fieldwork/Practicum in } \\
\text { Teacher Education Development Study-Mathematics' } \\
\text { (TEDS-M) Mathematics Education, Teaching issues about } \\
\text { Problem Solving in Mathematics Education, Learning and } \\
\text { Teaching, Teaching Practices, Probability Teaching and } \\
\text { Learning. Issues about In-service Teacher: Mathematics } \\
\text { Teacher Identity, Mathematical Knowledge for Teaching, } \\
\text { Teacher as Researcher in Mathematics Education, } \\
\text { Pedagogical Content Knowledge in Mathematics } \\
\text { Education, Teacher Beliefs, Attitudes and Self-Efficacy in } \\
\text { Mathematics Education, Values in Mathematics Education, } \\
\text { Mathematics Teacher as Learner (Lerman, 2001) }\end{array}$ \\
\hline $\begin{array}{l}\text { Research } \\
\text { Group } 2\end{array}$ & $\begin{array}{l}\text { Students and } \\
\text { Learning }\end{array}$ & $\begin{array}{l}\text { "Learning" is really enculturation. One "learns" by } \\
\text { becoming part of a viable culture. Whatever the apparent } \\
\text { "content" whether it will be mathematics or law or history } \\
\text { or repairing dishwashers, or the culture of lawyers, or the } \\
\text { culture of those who repair dishwashers. Process standards } \\
\text { for Learning; Problem-solving, Reasoning and Proof, } \\
\text { Communication, Connection, Representation (NCTM, } \\
2000 \text { ) }\end{array}$ \\
\hline $\begin{array}{l}\text { Research } \\
\text { Group } 3\end{array}$ & Assessment & $\begin{array}{l}\text { Assessment is the process of gathering and evaluating the } \\
\text { information on what students know, understand, and can do } \\
\text { in order to make an informed decision about the next steps } \\
\text { in the educational process (Clarke, 2012). Assessment and } \\
\text { the teaching process; before teaching, during teaching, and } \\
\text { after teaching (Lamprianou \& Athanasou, 2009). }\end{array}$ \\
\hline $\begin{array}{l}\text { Research } \\
\text { Group } 4\end{array}$ & $\begin{array}{l}\text { Classroom } \\
\text { innovations }\end{array}$ & $\begin{array}{l}\text { The key to classroom innovations is students are self- } \\
\text { regulated in their learning and the learning process is their } \\
\text { individual practice. The teacher plays the roles as leader } \\
\text { and facilitator to strengthen their relationship with students } \\
\text { as well as among students. Classroom management is } \\
\text { defined as has now become a whole-collective effort and } \\
\text { not limited to teacher's full responsibility (Inprasitha, 2004; } \\
\text { Sholes, 2018) }\end{array}$ \\
\hline $\begin{array}{l}\text { Research } \\
\text { Group } 5\end{array}$ & $\begin{array}{c}\text { Curriculum } \\
\text { development }\end{array}$ & $\begin{array}{l}\text { Classify the levels of courses for research studies as } \\
\text { follows: Intended Curriculum, Implemented Curriculum, } \\
\text { Attained Curriculum (Kilpatrick, 2009; Inprasitha, 2015b) }\end{array}$ \\
\hline $\begin{array}{l}\text { Research } \\
\text { Group } 6\end{array}$ & Educational policy & $\begin{array}{l}\text { The policy has four scopes: Research on policy } \\
\text { formulation, Studies on the status of policy, Research on } \\
\text { policy implementation, and Research on the effects of } \\
\text { policy (Ferrini-Mundy \& Floden, 2007) }\end{array}$ \\
\hline
\end{tabular}

The enabling environment in which the synthesis was situated including the policy context, the implementation of the LS and OA innovations themselves, and the abilities of individuals involved to undertake the synthesis and act on the research findings. Researchers 
adopted Inprasitha's (2004) classification as the guidelines to investigate and synthesize according to the six research classifications in this study.

\section{Results of Distribution of Research Context}

The research results revealed that there were a total of 210 studies $(78.95 \%)$ out of 266 studies were conducted using the Thailand LS Model. This implies that the Thailand LS Model is a popular topic among postgraduate researchers. Figure 2 demonstrates the distribution of the research context.

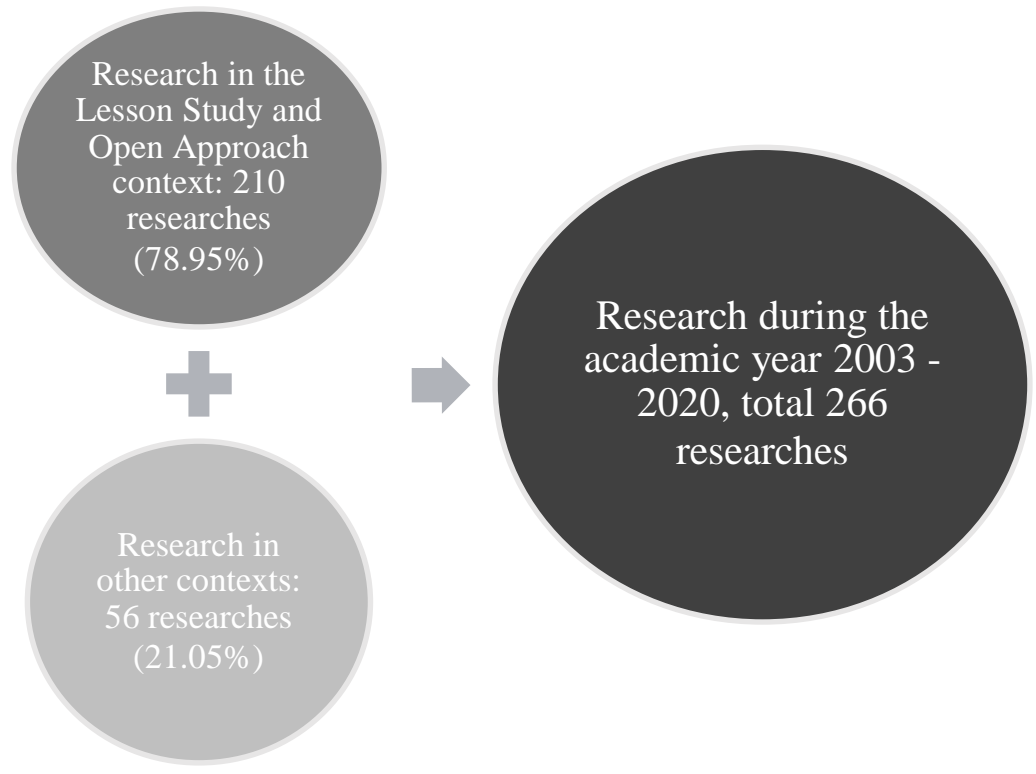

Figure 2. Distribution of research context

This is followed by using three stages to synthesize 210 postgraduate studies according to the classification made in Table 1. At the first stage, researchers began to classify each postgraduate study into the related category by analyzing the contents of the 210 postgraduate studies. Three areas of content were justified by researchers before making the classification, namely mathematical thinking development, LS, and OA innovations. Then researchers developed a framework based on the content analysis results for the purpose of synthesizing the postgraduate studies into the six research groups of classification as the second stage of analyzing data. Table 2 and Figure 3 illustrate the results of the second stage of this study.

Table 2 shows that the majority (112) or more than half $(53.33 \%)$ of the total postgraduate studies were found focusing their investigations on the research classification of students and learning. This is followed by $40(19.05 \%)$ studies in the research classification of teacher and teaching, $31(14.76 \%)$ studies in the research classification of classroom innovations, 10 $(4.76 \%)$ studies in the research classification of assessment, and nine $(4.29 \%)$ studies in the research classification of curriculum development. The least studies $(3.81 \%)$ or only eight studies focused on the research classification of educational policy.

Table 2. Descriptive Results of Postgraduate Studies Classification

\begin{tabular}{|c|c|c|c|}
\hline $\begin{array}{c}\text { Research } \\
\text { Group }\end{array}$ & Name of Research Group & Frequency & Percentage \\
\hline Research Group 1 & Teacher and Teaching & 40 & 19.05 \\
\hline Research Group 2 & Students and Learning & 112 & 53.33 \\
\hline
\end{tabular}




\begin{tabular}{|c|c|c|c|}
\hline Research Group 3 & Assessment & 10 & 4.76 \\
\hline Research Group 4 & Classroom innovations & 31 & 14.76 \\
\hline Research Group 5 & Curriculum development & 9 & 4.29 \\
\hline Research Group 6 & Educational policy & 8 & 3.81 \\
\hline \multicolumn{2}{|c|}{ Total } & 210 & 100.00 \\
\hline
\end{tabular}

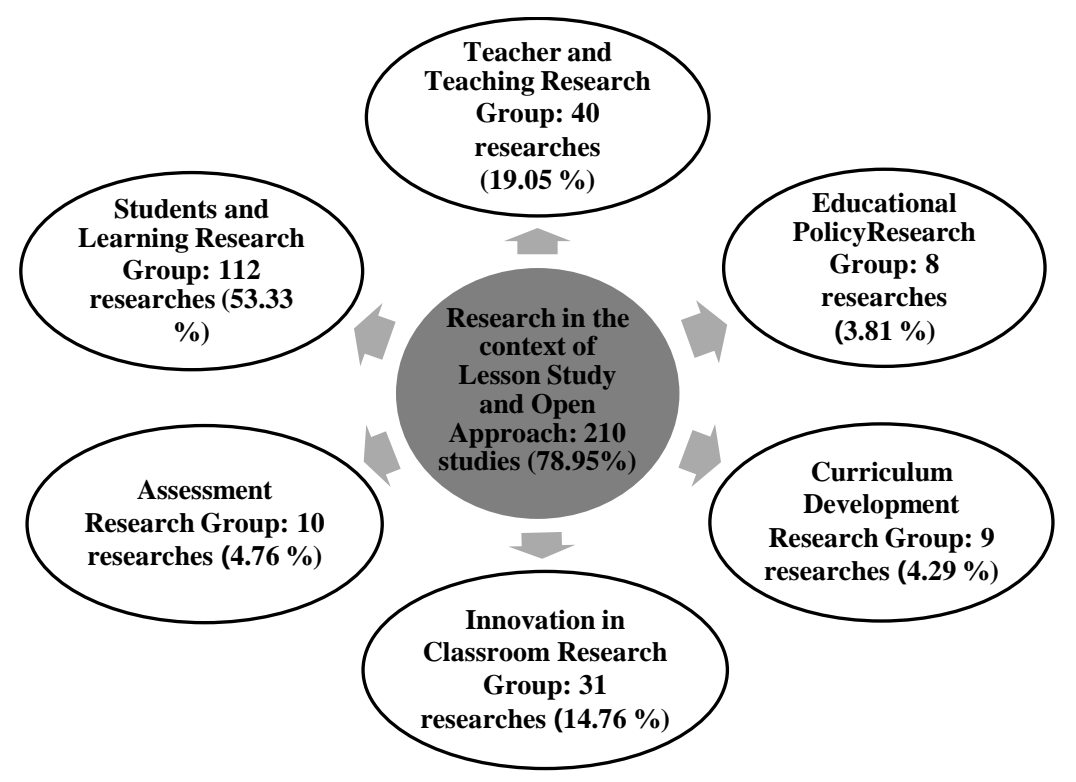

Figure 3. Distribution of research classification

\section{Results of Mathematical Thinking Development}

The third phase of this research was to gather relevant facts or issues related to mathematical thinking development from the 210 postgraduate studies concerning the six research classifications.

\section{Teacher and Teaching Research}

The synthesis results from the 40 postgraduate studies indicated that previous postgraduate researchers designed the open-ended problem situations to encourage students for learning and developing their mathematical thinking. On the other hand, their findings imply that teachers must have their values, beliefs, roles, and contexts as well as they must refer to guidelines. Therefore, researchers concluded that teachers must build their beliefs, values, and identify their roles when they are conducting problem-solving teaching to develop their students' mathematical thinking.

\section{Student and Learning}

The synthesis results from the 112 postgraduate studies revealed that past postgraduate researchers were generally emphasizing these issues of student learning, namely mathematical conceptual understanding, creation awareness, reasoning strategies for problem-solving, students' self-regulated in solving problems, nature of learning, and critical learning. All these research issues were considered essential because they could assist students to develop their mathematical thinking. For example, students can think independently because they are aware of the mathematical concepts that lead them to use the concepts as tools for further their learning. 


\section{Assessment}

The synthesis results from the 10 postgraduate studies highlighted the importance of designing open-ended problems by modifying the assessment focus. Their findings imply that students should be allowed to develop their conceptual understanding to solve the problem situations at their own pace and independently. The assessments should be developed to observe students' ideas that lead to their learning development.

\section{Classroom Innovations}

The synthesis results from the 31 research related to classroom innovations that had been conducted by postgraduate students were mainly using open-ended problem situations as the starting point before they applied OA as a treatment in the LS process. Their research mainly aimed to investigate students' mathematical thinking development by focusing on their ideas that arising to solve the problem situations by themselves while teachers were applying the OA and LS innovations.

\section{Curriculum Development}

The synthesis results from the nine research that associated with curriculum development showed that students' self-learning and the development of their ideas are the two main causes to enhance students' mathematical thinking through curriculum implementation and development. Students managed to create more ideas after they had discussed with their peers who might have different ideas. This was ultimately helping students' thinking and curriculum development and growth.

\section{Educational Policy}

Although there was quite limited of past postgraduate studies, only eight research in educational policy research classification, but their findings still showed the significance of LS and OA innovations as teacher professional learning. Their findings revealed that teacher professional learning using LS and OA innovations is one of the requirements of educational policy aimed at building teachers' capabilities to make mathematics learning deeper and more engaging. For example, teachers collaborated to design quality mathematics activities, using OA teaching strategies to encourage students' metacognition and mindsets growth as students progress in mathematics learning and made a commitment to apply mathematics ideas in their mathematics lessons. Moreover, teachers also discussed actively researchinformed strategies during the reflection section that were demonstrated in the professional learning sessions.

\section{CONCLUSION}

This exploratory review of 210 postgraduate studies from the academic year 2003 to 2020 found a range of impacts from qualitative educational research synthesis and assumptions underpinning the relationship between research synthesis and impacts. The synthesis initiatives examined have contributed to the impacts of LS and OA innovations in six research classifications of research, namely teacher and teaching, students and learning, assessment, classroom innovations, curriculum development, and educational policy to enhance students' mathematical thinking development.

The research classifications of impacts used to support this analysis provide a framework through which to understand and interrogate the various types of impacts synthesis research are having, and the assumptions underpinning the relationship between synthesis and impact (Wyborn et al., 2018). This is enabling researchers to be more explicit about the intended role and contribution of synthesis to mathematical thinking developmental change and will further enable an examination of whether these assumptions and the validity as initiative 
progress of LS and OA. Furthermore, being explicit about these assumptions from the outset will enable an initiative to consider the range of institutional support and capacities needed to realize changes in policy and practice.

\section{ACKNOWLEDGMENTS}

This research is "Supported by Research and Graduate Studies" Khon Kaen University, Thailand.

\section{REFERENCES}

Abdul Hamid, N. H., \& Kamarudin, N. (2021). Assessing students' mathematics achievement and mathematics creativity using mathematical creative approach: A quasiexperimental research. Asian Journal of University Education, 17(2), 100-112.

Ailinger, R. (2003). Contributions of qualitative evidence based practice in nursing. Rev Latino-Am Enfermagem, 11, 275-279.

Barber, K. (2018). Developing teachers' mathematical-task knowledge and practice through Lesson Study. International Journal for Lesson and Learning Studies, 7(2), 136-149. https://doi.org/10.1108/IJLLS-09-2017-0042

Baron, J. S., Specht, A., Garnier, E., Bishop, P., Campbell, C. A., Davis, F. W., \& Winter, M. (2017). Synthesis centers as critical research infrastructure. BioScience, XX(X), 1-10. http://dx.doi.org/10.1093/biosci/bix053.

Bowen, G. A. (2009). Document analysis as a qualitative research method. Qualitative Research Journal, 9(2), 27-40. https://doi.org/10.3316/QRJ0902027

Chikusvura, N., Sibanda, L., \& Mathwasa, J. (2021). The Competence-Based Advanced Level Mathematics Curriculum: Implications for Students' Enrolment in one University in Zimbabwe. Randwick International of Education and Linguistics Science Journal, 2(1), 8-19. https://doi.org/10.47175/rielsj.v2i1.194

Chaona, S., Inprasitha, M., Changsri, N., \& Sangaroon, K. (2021). Mathematics educators' perspective on pre-service mathematics teachers' professional competencies. International Educational Research, 4(1), 55-60. https//doi.org/0.30560/ier.v4n1p55

Clarke, M. (2012). What matters most for student assessment systems: a framework paper. Systems Approach for Better Education Results (SABER) student assessment working paper no. 1. Washimgton, DC: World Bank.

Coenders, F., \& Verhoef, N. (2019). Lesson study: Professional development (PD) for beginning and experienced teachers. Professional Development in Education, 45(2), 217 230 .

English, L. (2020). Teaching and learning through mathematical problem posing: Commentary. International Journal of Educational Research, 102. https://doi.org/10.1016/j.ijer.2019.06.014

Ferrini-Mundy, J. \& Floden, R.E. (2007). Educational Policy Research and Mathematics Education. In F.K.Lester, Jr. (Ed). Second Handbook of Research OnMathematics Teaching and Learning (pp. 1247-1279). Chariotte. NC: Information Age Publishing.

Ghazali, N., Nordin, M. S., Abdullah, A., \& Ayub, A. F. (2020). The relationship between students' MOOC-efficacy and meaningful learning. Asian Journal of University Education, 16(3), 89-101. https//doi.org/10.24191/ajue.v16i3.11071

Hrastinski, S. (2021). Digital tools to support teacher professional development in lesson studies: A systematic literature review. International Journal for Lesson \& Learning Studies, 10(2), 138-149.

Inprasitha, M. (2004). Teaching by using open approach in mathematics classroom of Japan. KKU Journal of Mathematics Education 1, p. 3 
Inprasitha, N. (2009). Lesson Study: Innovation for developing teacher and students. Doctor of Education thesis. Khon Kaen, Thailand: Khon Kaen University.

Inprasitha, M. (2011). One feature of adaptive Lesson Study in Thailand: Designing a learning unit. Journal of Science and Mathematics Education in Southeast Asia, 34(1), pp. 47-66.

Inprasitha, M. (2015a). An open approach incorporating lesson study: An innovation for teaching whole number arithmetic. Proceedings of ICMI Study 23: Primary Mathematics Study on Whole Numbers. (pp. 315-322). China: Macao.

Inprasitha, M. (2015b). New model of teacher education program in mathematics education: Thailand experience. Paper presented at the ICMI-East Asia Regional Conference on Mathematics Education, Cebu City, the Philippines, May 11-15.

Inprasitha, M. (2018). How Lesson Study enhance new school mathematics. Paper presented at World Association of Lesson Studies (WALS) International Conference, Beijing Normal University, China, November 23-26.

Isoda, M., \& Katagiri, S. (2012). Mathematical thinking: How to develop it in the classroom. In K. Stacey, D. Tall, M. Isoda, and M. Inprasitha (Eds.), Chapter 3: The mindset and mathematical thinking. Singapore: World Scientific.

Jaikla, J., Inprasitha, M., Changsri, N. (2021). An analysis of students' mathematical competencies: The relationship between units. International Educational Research, 4(1), 29-37. https//doi.org/10.30560/ier.v4n1p29

Jordan, Z., Donnelly, P., \& Pittman, P. (2006). A short history of a big idea. Melbourne, Australia: The Joanna Briggs Institute.

Kertil, M., \& Gurel, C. (2016). Mathematical modeling: A bridge to STEM education. International Journal of Education in Mathematics, Science and Technology, 4(1), $44-$ 55. https//doi.org/10.18404/ijemst.95761

Kesorn, N., Junpeng, P., Marwiang, M., Pongboriboon, K., Tang, K. N., \& Wilson, M. (2020). Development of an assessment tool for mathematical reading, analytical thinking and mathematical writing. International Journal of Evaluation and Research in Education, 9(4), 955-962. https//doi.org/10.11591/ijere.v9i4.20505

Kilpatrick, J. (1992). A history of research in mathematics education. In Grouws, D. A. (Ed.). Handbook of Research on mathematics teaching and learning. (pp. 3-38). 6. United States of America: The National Council of Teacher of Mathematics.

Kilpatrick, J. (2009). The mathematics teacher and curriculum change. PNA, 3(3), 107-121.

Laah-on, S., Inprasitha, M., Sangaroon, K., \& Changsri, N. (2021). Using classroom video in designing open-ended problem situations. International Educational Research, 4(1), 46-54. https//doi.org/10.30560/ier.v4n1p46

Lalima, \& Dangwal, K. L. (2017). Blended learning: An innovative approach. Universal $\begin{array}{llll}\text { Journal of Educational } & \text { Research, } & 5(1), & 129-136 .\end{array}$ https://doi.org/10.13189/ujer.2017.050116

Lamprianou, I. \& Athanasou, J.A. (2009). A teacher's Guide to Educational Assessment. Rotterdam: Sense Publishers.

Lee, A. R., \& Bailey, D. R. (2020). Examining South Korean university students' interactions with international students. Asian Journal of University Education, 16(3), 4358.

Leikin, R., \& Elgrably, H. (2020). Problem posing through investigations for the development and evaluation of proof-related and creativity skills of prospective high school mathematics teachers. International Journal of Educational Research, 102. https://doi.org/10.1016/j.ijer.2019.04.002 
Lerman, S. (2001). A review of research perspectives on mathematics teacher education. Making sense of mathematics teacher education, 33-52. Dordrecht: Springer.

Lesh, R. \& Doerr, H. M. (2003). Foundations of a models and modeling perspective on mathematics teaching, learning, and problem solving. In R. Lesh and H. M. Doerr (Eds.), Beyond constructivism: Models and modeling perspectives on mathematics problem solving, learning, and teaching (pp. 3-33). Mahwah, NJ: Lawrence Erlbaum Associates.

Lewis, C. C., Perry, R. R., \& Murata, A. (2006). How should research contribute to instructional improvement? The case of lesson study. Educational Researcher, 35(3), 314.

Lockwood, C., Munn, Z., \& Porritt, K. (2015). Qualitative research synthesis: A methodological guidance for systematic reviewers utilizing meta-aggregation. International Journal of Evidence-based Healthcare, 13(3), 179-187. https://doi.org/10.1097/XEB.0000000000000062

Manmai, T., Inprasitha, M., Changsri, N., \& Pattanajak, A. (2020). Development of reasoning habits through lesson study and open approach teaching practices. International Educational Research, 3(2), 29-36.

Munn, Z., Porritt, K., Lockwood, C., Aromataris, E. (2014). Establishing confidence in the output of qualitative research synthesis: The ConQual approach. BMC Med Res Methodol, 14, 7.

Murata, A. (2011). Introduction: Conceptual overview of Lesson Study. In Hart, L. C. et al. (Eds), Lesson Study Research and Practice in Mathematics Education, Springer, pp. 112.

National Council of Teachers of Mathematics (NCTM). (2000). Principles and Standards for School Mathematics. Reston, VA: National Council of Teachers of Mathematics.

O'Leary, Z. (2014). The essential guide to doing your research project $\left(2^{\text {nd }} \mathrm{ed}\right.$.). Thousand Oaks, CA: Sage.

Pape, S. J., Bell, C. V., \& Yetkin, I. E. (2003). Developing mathematical thinking and selfregulated learning: A teaching experiment in a seventh-grade mathematics classroom. Educational Studies in Mathematics, 53, 179-202.

Schoenfeld, A. (1985). Mathematical problem solving. Orlando, FL: Academic Press.

Shimizu, Y. (1999). Aspect of mathematics teacher education in Japan: Focusing on teachers' roles. Journal of Mathematics Teacher Education, 2(1), 107-116.

Sholes, R. (2018). Innovation Classroom Strategies. https://victoryprd.com/blog/innovativeclassroom-strategies/

Stacey, K. (2006). What is mathematical thinking and why is it important? Retrieved from file:///C:/Users/ED/Downloads/WHAT_IS_MATHEMATICAL_THINKING_AND_W HY_IS_IT_IMPORT.pdf

Stigler, J. W., \& Hiebert, J. (1999). The teaching gap: Best ideas from the world's teachers for improving education in the classroom. New York, NY: The Free Press.

Vermunt, J. D., Vrikki, M., van Halem, N., Warwick, P., \& Mercer, N. (2019). The impact of Lesson Study professional development on the quality of teacher learning? Teaching and Teacher Education, 81, 61-73.

Wyborn, C., Louder, E., Harrison, J., Montambault, J., Montana, J., Ryan, M., ..., Hutton, J. (2018). Understanding the impacts of research synthesis. Environmental Science and Policy, 86, 72-84. 